\title{
Biodegradable and photocrosslinkable polyphosphoester
}

\section{hydrogel}

\author{
Qiang Lia , Jun Wang ${ }^{b}$, Shilpa Shahania , Danny D.N. Suna, Blanka Sharmaa, Jennifer H. \\ Elisseeff ${ }^{a}, 1$, and Kam W. Leong ${ }^{a}{ }^{\star}$ \\ aDepartment of Biomedical Engineering, The Johns Hopkins University, Baltimore, MD, USA \\ bSchool of Life Sciences, and School of Chemistry and Material Science, University of Science and Technology \\ of China, Hefei, China
}

\begin{abstract}
A new biodegradable, photocrosslinkable and multifunctional macromer, poly(6-aminohexyl propylene phosphate) (PPE-HA)-ACRL, was synthesized by conjugation of acrylate groups to the side chains of PPE-HA. By controlling the synthetic conditions, different weight fractions of acrylate in the macromers were achieved as confirmed by ${ }^{1} \mathrm{H}$ NMR. The hydrogels obtained from PPE-HAACRL through photocrosslinking were dominantly elastic. With increasing acrylate contents in the macromers, the hydrogels exhibited a lower swelling ratio and higher mechanical strength. The hydrogels with different crosslinking densities lost between $4.3 \%$ and $37.4 \%$ of their mass in 84 days when incubated in phosphate-buffered saline at $37^{\circ} \mathrm{C}$. No significant cytotoxicity of the macromers against bone marrow-derived mesenchymal stem cells from goat (GMSC) was observed at a concentration up to $10 \mathrm{mg} / \mathrm{ml}$. Finally, GMSCs encapsulated in the photopolymerized gel maintained their viability when cultured in osteogenic medium for three weeks. Clear mineralization in the hydrogel scaffold was revealed by Von Kossa staining. This study suggests the potential of these biodegradable and photocrosslinkable as injectable tissue engineering scaffolds.
\end{abstract}

\section{Keywords}

Polyphosphoester; Photopolymerization; Hydrogel; Tissue engineering scaffold; Osteogenesis

\section{Introduction}

Hydrogel scaffolds are attractive for applications in drug/gene delivery and tissue engineering [1-5]. As insoluble three-dimensional hydrophilic networks, hydrogels can retain a high amount of water, contributing to their good biocompatibility and maintaining a certain degree of structural integrity and elasticity. For drug and gene delivery applications, biodegradability would be a desirable trait of the hydrogel. For tissue engineering, in addition to

biodegradability, the ability to form the hydrogel in situ would be attractive. The latter would allow delivery of drugs or cells entrapped in the hydrogel to the target tissue through injection. If the hydrogel were also amenable to ligand conjugation, its appeal would be further enhanced as a bioactive carrier or scaffold. In this study, we propose to develop such a hydrogel system by conjugating an acrylated-PEG to the side chain of a biodegradable polyphosphate.

\footnotetext{
*Corresponding author. Department of Biomedical Engineering, Johns Hopkins University, 720 Rutland Ave./Ross Building 726, Baltimore, MD 21205, USA. Tel.: +1 410614 3741; fax: +1 410955 0549. E-mail addresses: jhe@ bme.jhu.edu (J.H. Elisseeff), kleong@bme.jhu.edu (K.W. Leong).

$1_{1}$ Also to be corresponded to. Department of Biomedical Engineering, Johns Hopkins University, 3400 North Charles Street/Clark 106, Baltimore, MD 21218, USA, Tel.: +1 410516 4915; fax: +1 4105168152
} 
Polyphosphoester (PPE), or polyphosphate when the side chain linking to the phosphorus atom is an alkoxy group, has been proposed for biomedical applications because of its biodegradability, potential biocompatibility and versatility [6-8]. With judicious choice of aliphatic structures in the backbone and the side chain, the polymers can breakdown into nontoxic products. They have been applied in the biomaterials field as tissue engineering scaffold, drug carrier and gene carrier [9-13]. Poly(6-aminoethyl propylene phosphate) (PPEEA) has been investigated as a gene carrier and showed promising biocompatibility and degradation behavior $[11,12]$. In that design, the primary amino groups in the side chain provide the cationicity to condense the DNA. It occurred to us that a portion of these primary amino groups could also be used to conjugate crosslinkable moieties for the biodegradable hydrogel design described above. We achieved this by linking an acrylate group to the side chain via a poly(ethylene glycol) (PEG) spacer. The properties of this crosslinkable macromonomer can be varied by the degree of substitution in the side chain and the length of the PEG spacer.

Operational at low temperature, under aqueous condition, and requiring low initiator concentration, photopolymerization can minimize the damage to the entrapped bioactive agents or cells during the hydrogel formation. Spatial and temporal control of gelation may also be achieved [14-18]. Although a number of photocrosslinkable polymer systems have been developed in the past decade, only a few synthetic polymer systems are also biodegradable [17-19]. The biodegradability of the PPE hydrogel design can be readily adjusted by varying the molar content of the acrylate group in the side chain. Another interesting feature of the PPE design is the known chelation of phosphate with calcium. Various forms of calcium phosphate have been incorporated into different scaffolding designs for repair and reconstruction of bone tissues [20-23]. We therefore hypothesized that these biodegradable and photocrosslinkable PPE hydrogels might make interesting scaffolds for bone tissue engineering.

In this study, we synthesized three macromers with different acrylate contents and studied their cytotoxicity in vitro, as well as the swelling behavior, degradation rate and mechanical property of the resulting hydrogels. We also encapsulated bone marrow-derived stem cells from goat (GMSC) in the hydrogels and investigated their viability and differentiation in osteogenic media.

\section{Materials and methods}

\subsection{Macromer synthesis}

All chemicals were purchased from Sigma-Aldrich Corp. (St. Louis, MO), unless otherwise stated.

Poly(6-aminohexyl propylene phosphate) (PPE-HA) was synthesized as described elsewhere $[11,12]$. To a solution of PPE-HA in phosphate buffer (PB, $0.1 \mathrm{~m}, \mathrm{pH} 7.4$ ) was added ACRLPEG-NHS (MW 3400 Da) (Nektar Therapeutics Corp., Huntsville, AL) solution in PB (Scheme 1A) at three different molar ratios as shown in Table 1. The mixture was allowed to stand at $4{ }^{\circ} \mathrm{C}$ for $16 \mathrm{~h}$. Three different macromer series were synthesized using a molar ratio of ACRL-PEG-NHS to PPE-HA at 4:10 for PPE-HA-ACRL-1, 2:10 for PPE-HA-ACRL-2 and 1:10 for PPE-HA-ACRL-3. The products were purified with centrifugal filtration devices (Millipore Corp., Bedford, MA), dried by lyophilization and stored at $-20{ }^{\circ} \mathrm{C}$ before use. For ${ }^{1} \mathrm{H}$ NMR, $50 \mathrm{mg}$ PPE-HA-ACRL was dissolved in $1.0 \mathrm{ml} \mathrm{D}_{2} \mathrm{O}$ and spectra were acquired with a Unity Plus $400 \mathrm{MHz}$ spectrometer (Varian Associates) to analyze the conjugation efficiency of ACRL-PEG-NHS to the PPE-HA side chains. 


\subsection{Photopolymerization}

One hundred and fifty microliter of macromer solution (20\% w/v in deionized water) were placed in tissue culture inserts (diameter $8 \mathrm{~mm}$ ) and polymerized for $8 \mathrm{~min}$ at $365 \mathrm{~nm}$ UV light at $\sim 8-20 \mathrm{~mW} / \mathrm{cm}^{2}$ in the presence of initiator (Irgacure D-2959, 0.05\% (w/w), Ciba Geigy) [24-26]. The light intensity was determined by radiometer.

\subsection{Swelling and degradation assays}

The swelling assay was conducted on the hydrogels obtained with a light intensity of $20 \mathrm{~mW} /$ $\mathrm{cm}^{2}$ in order to get a complete reaction of the macromers. After photopolymerization, the samples were transferred and incubated in $2 \mathrm{ml}$ of PBS $(0.01 \mathrm{M}, \mathrm{pH} 7.4)$ at $37^{\circ} \mathrm{C}$. Swollen samples were weighted as $W_{\mathrm{w}}$ at different time points. The dry weight $\left(W_{\mathrm{d}}\right)$ was measured after lyophilization. The equilibrated swelling ratio, $q$, was calculated by $q \approx W_{\mathrm{w}} / W_{\mathrm{d}}$. In a separate experiment the hydrogel samples were rinsed with deionized water, lyophilized and weighed $\left(W_{\mathrm{i}}\right)$. The dried hydrogel samples were incubated in $2 \mathrm{ml}$ of phoshate-buffered saline PBS $(0.01$ м, pH 7.4) at $37^{\circ} \mathrm{C}$ and shaken at 100 r.p.m. on an orbital shaker. The PBS medium was replaced daily for the first week and weekly for the rest of the study. At pre-determined time points, specimens were rinsed with deionized water, lyophilized and weighed $\left(W_{\mathrm{d}}\right)$. The percent weight loss was calculated as $\left(W_{\mathrm{i}}-W_{\mathrm{d}}\right) / W_{\mathrm{i}} \times 100$. Both experiments were performed in triplicate.

\subsection{Rheological assay}

Hydrogels obtained with a light intensity of $20 \mathrm{~mW} / \mathrm{cm}^{2}$ were subjected to rheological tests performed on an RFS-3 rheometer (Rheometric Scientific Inc.) using the parallel-plate configuration [25,27]. The pilot dynamic shear strain-sweep test at a frequency of $6.28 \mathrm{rad} / \mathrm{s}$ indicated that the $0.1 \%$ shear strain was in the linear stress-strain range for the different PPEHA-ACRL samples. Such linearity was confirmed for each test sample prior to the dynamic shear frequency-sweep test, which covered a range of frequencies from 1 to $100 \mathrm{rad} / \mathrm{s}$ at a shear amplitude of $0.1 \%$.

\subsection{Cell isolation and expansion}

Bone marrow from the iliac crest of three to three-and-a-half year old, castrated male goats being sacrificed for other reasons was aspirated into 10-ml syringes with 6000 units of heparin and processed within $4 \mathrm{~h}$ of harvest. The marrow samples were washed and centrifuged twice (1000 r.p.m. for $10 \mathrm{~min}$ ) in mesenchymal stem cell growth media (MSCGM; Poetics, BioWhittaker Inc., Walkersville, MD) prior to suspension in fresh MSCGM. The number of mononuclear cells was counted with a hemocytometer and plated in $75 \mathrm{~cm}^{2}$ tissue culture plastic flasks at a density of approximately 12,000 mononuclear cells $/ \mathrm{cm}^{2}$. The first medium change occurred after 4 days and then every 2-3 days thereafter until confluency (12-14 days). Cells were passaged with $0.025 \%$ Trypsin/EDTA (Clonetics, BioWhittaker Inc., Walkersville, MD) for $5 \mathrm{~min}$ at $37^{\circ} \mathrm{C}$ and replated at $5000 \mathrm{MSCs} / \mathrm{cm}^{2}$. MSCs were frozen in liquid nitrogen in 50\% MSCGM, 40\% FBS (Hyclone, Logan, UT), and 10\% DMSO until needed. Cell viability after thawing was consistently above $92 \%$. When needed, the frozen cells were thawed, plated at 5000 cells $/ \mathrm{cm}^{2}$ in $175 \mathrm{~cm}^{2}$ flasks in MSCGM and grown at $37{ }^{\circ} \mathrm{C}, 95 \%$ humidity and $5 \%$ $\mathrm{CO}_{2}$ until confluent with media changed twice weekly.

\subsection{Cytotoxicity of macromers}

Mesenchymal stem cells isolated from goats (GMSC) above were seeded in 96-well plates at a density of $1.5 \times 10^{4}$ cells $/ \mathrm{cm}^{2}$. The plate was incubated for $24 \mathrm{~h}$ at $37{ }^{\circ} \mathrm{C}, 95 \%$ humidity and $5 \% \mathrm{CO}_{2}$ until cells reached 80-90\% confluency in the well. The GMSC medium was then replaced with mesenchymal stem cell growth medium containing PPE-HA-ACRL-1 or PPEHA-ACRL-3 at concentrations ranging from 0.01 to $10 \mathrm{mg} / \mathrm{ml}$. Normal GMSC culture medium without any macromer solution was used as positive controls. The cells were further incubated 
for $24 \mathrm{~h}$. Then, the medium was replaced with $100 \mu \mathrm{l}$ of fresh mesenchymal stem cell growth medium containing $10 \times$ diluted PreMix WST-1 (Takara Bio Inc., Otsu Shiga, Japan) and the cells were incubated for another $4 \mathrm{~h}$ at $37{ }^{\circ} \mathrm{C}, 95 \%$ humidity and $5 \% \mathrm{CO}_{2}$. The absorbance of the medium was measured at $440 \mathrm{~nm}$ with Microtiter plate (ELISA) reader (BIO-TEK Instruments Inc., Winooski, VT).

\subsection{Cell encapsulation and cultivation}

GMSCs (passage 2) were suspended in a solution of PPE-HA-ACRL-1 in PBS (20\% (w/v)) with $100 \mathrm{U} / \mathrm{ml}$ penicillin $\mathrm{G}$ and $100 \mu \mathrm{g} / \mathrm{ml}$ streptomycin (Gibco). The final concentration of cells was $20 \times 10^{6}$ cells $/ \mathrm{ml}$. After addition of $0.05 \%$ Irgacure D-2959 (w/v), the solution was photopolymerized for $8 \mathrm{~min}$ with $8 \mathrm{~mW} / \mathrm{cm}^{2} \mathrm{UV}$ light. The resulting hydrogels were transferred into $2 \mathrm{ml}$ osteogenic medium (OM) [28,29] (450 ml high glucose DMEM (no pyruvate, Gibco), $100 \mathrm{n}_{\mathrm{M}}$ dexamethasone, $50 \mu_{\mathrm{M}}$ ascorbic-2-phosphate (Gibco), $10 \mathrm{~m}_{\mathrm{n}} \beta$-glycerophosphate, $10 \%$ fetal bovine serum (FBS, BD Biosciences, Bedford, MA), $100 \mathrm{U} / \mathrm{ml}$ penicillin and $100 \mu \mathrm{g} / \mathrm{ml}$ streptomycin (Gibco)). The medium was changed 3 times a week and the culture plates were changed once a week.

\subsection{Histology}

At the end of 1 and 3 weeks of cultivation, the hydrogel constructs were immersed in $10 \%$ formaldehyde ( $\mathrm{pH} \mathrm{7.4)}$ ) at $4{ }^{\circ} \mathrm{C}$ overnight and then the solution was changed to $70 \%$ ethanol. The samples were sectioned and stained with H\&E and Von Kossa by Histoserv Inc.

(Germantown, MD).

\section{Results and discussion}

\subsection{Synthesis of macromer}

The macromers were synthesized by coupling acrylated PEG to the side chain of the biodegradable polyphosphoester PPE-HA, which has a $\bar{M} w=3.76 \times 10^{4}$ and a $\bar{M} n=2.79 \times 10^{4}$. The polymer underwent degradation when incubated in PBS at $37^{\circ} \mathrm{C}$ due to the hydrolytic cleavage of the phosphoester bonds in the backbone as well as the side chain $[11,12]$. In a previous study, the $M w$ of PPE-HA dropped $50 \%$ in 20 days, followed by another $20 \%$ decrease in the next 30 days. In this study, the conjugation reaction of acrylated PEG to the polymer was therefore performed at $4{ }^{\circ} \mathrm{C}$ to reduce the hydrolytic cleavage of the PPE-HA side chain and to minimize the side reactions of the acrylate group. The synthetic scheme for these macromers is illustrated in Scheme 1A, and the composition of the different macromers is shown in Table 1.

The representative ${ }^{1} \mathrm{H}$ NMR of PPE-HA-ACRL is shown in Fig. 1 . The alphabetically labeled peaks are assigned to the corresponding protons shown in Scheme 1B. Typically, protons $\left({ }^{3} \mathrm{H}\right)$ of the acrylate groups $\left(\mathrm{CH}_{2}=\mathrm{CH}\right)\left(\mathrm{H}_{\mathrm{a}}\right.$ and $\left.\mathrm{H}_{\mathrm{b}}\right)$ gave peaks at 6.45, 6.22 and $5.99 \mathrm{ppm}$, respectively. Protons $\left({ }^{4} \mathrm{H}\right)$ from $\mathrm{O}-\mathrm{CH}\left(\mathrm{CH}_{3}\right) \mathrm{CH}_{2} \mathrm{O}\left(\mathrm{H}_{\mathrm{c}}\right)$ in the backbone and $\mathrm{O}-$

$\mathrm{CH}_{2} \mathrm{CH}_{2} \mathrm{CH}_{2}-\left(\mathrm{H}_{\mathrm{c}}\right)$ of the side chains gave an overlapped peak at 4.02 to $4.3 \mathrm{ppm}$. Protons of the methylene group $\left(\mathrm{O}-\mathrm{CH}_{2} \mathrm{CH}_{2} \mathrm{CH}_{2} \mathrm{CH}_{2} \mathrm{CH}_{2} \mathrm{CH}_{2} \mathrm{NH}_{2}\right)\left(\mathrm{H}_{\mathrm{d}}\right)$ adjacent to the unreacted amino groups showed a triplet at $2.99 \mathrm{ppm}$. This peak shifted to $3.18 \mathrm{ppm}\left(\mathrm{H}_{\mathrm{e}}\right)$ when the amino groups reacted with ACRL-PEG-NHS. The protons from the methylene group next to the carbonyl of the amide $\left(\mathrm{NH}-\mathrm{C}(\mathrm{O})-\mathrm{CH}_{2} \mathrm{CH}_{2}-\right)\left(\mathrm{H}_{\mathrm{f}}\right)$ were assigned to the triplet at $2.48 \mathrm{ppm}$. No specific peak attributable to NHS, which should be at $2.63 \mathrm{ppm}$, was found in the ${ }^{1} \mathrm{H}$ NMR spectra. The degree of PEG conjugation was calculated based on the integration of peaks at 2.48 and $2.99 \mathrm{ppm}$. The number of acrylate groups per 100 units was calculated according to the integration of peaks at 5.99 and $2.48 \mathrm{ppm}$. 
The reaction of ACRL-PEG-NHS with the amino groups of PPE-HA was selective and with high conversion efficiency, as shown in Table 1. The numbers of PEG chains conjugated to 100 polymer units were $37.9,22.6$ and 13.6 for PPE-HA-ACRL-1, -2 and -3, respectively. The corresponding free amino groups remaining in these macromers were $50.1 \%, 69.8 \%$ and $83.4 \%$. The number of double bonds supposedly at the terminals of PEG was less than that of the PEG chains, which is likely due to the impurity of the starting ACRL-PEG-NHS and the side reactions of the acrylate groups. Nevertheless, the derivatization was efficient. The ability to vary the amount of acrylated PEG in the macromer would allow one to balance the hydrophilicity of the resulting hydrogel and the rate of gelation. The former influences the cell viability and mechanical properties, while the latter determines the practical appeal of the injectable scaffold. A fast gelation rate is desirable. While this can be achieved by increasing the macromer concentration, the light incident intensity, or the photoinitiator concentration, none of this is desirable because of the unwelcome high viscosity for injection or the higher risk of damage to the cells. Increasing the acrylate density is a better approach to accelerate the gelation.

\subsection{Physical and chemical characterization}

The macromer solution was crosslinked to form a gel under UV irradiation at $365 \mathrm{~nm}$. Irgacure D-2959 was used as the initiator because of its relatively low cytotoxicity [24]. Hydrogels derived from PPE-HA-ACRL-1 and -2 reached the swelling equilibrium in 1 day, yielding a swelling ratio of 8.6 and 9.8, respectively. On the other hand, the PPE-HA-ACRL-3 hydrogel reached the swelling equilibrium in 4 days at a swelling ratio of 17.5 (Fig. 2). The difference is attributed to the relative PEG contents and crosslinking density of the hydrogels. It is important to control the equilibrium-swelling ratio and at the same time maintain a certain mechanical strength for tissue engineering applications. By adjusting the PEG-acrylate percentage in the PPE-HA side chains, in principle this balance could be manipulated for optimal performance in different applications.

The dynamic shear modulus $\left|G^{*}\right|$ and the phase shift angle $\delta$ of the hydrogels were measured by a dynamic frequency sweep test (Fig. 3). $\left|G^{*}\right|$, the norm of $G^{\prime}$ and $G^{\prime \prime}$, represents the aggregated stiffness of a viscoelastic material under dynamic conditions, while the phase shift angle $\delta\left(\tan \delta=G^{\prime \prime} / G^{\prime}\right)$ gives a measure of the energy dissipation $\left(G^{\prime \prime}\right)$ over storage $\left(G^{\prime}\right)$ [30]. As the acrylate content in the PPE-HA side chains increased, the elastic shear modulus $G^{\prime}$ increased from 3 to $26 \mathrm{kPa}$ (Fig. 3). The rising trend of elastic shear modulus with respect to acrylate content is consistent with the swelling data described above. On the other hand, the viscous shear modulus $G^{\prime \prime}$ was low for all acrylate contents, in the range of $0-2 \mathrm{kPa}$ (data not shown). Correspondingly, the phase shift angle was in the range of $0-5^{\circ}$ for all samples, signifying that the hydrogels mainly exhibited an elastic behavior with only a very small viscous component. The elastic property of a hydrogel is determined by the crosslinks and entrapped entanglements. The fact that the elastic modulus dominates the viscosity modulus, and the elastic modulus of PPE-HA-ACRL is not sensitive to the shearing frequency, suggests that the PPE-HA-ACRL chains are highly crosslinked and with little slippage.

Regarding the biodegradation of the hydrogels in PBS at pH 7.4 and $37^{\circ} \mathrm{C}$, PPE-HA-ACRL-3 degraded fastest, with a mass loss of $13.43 \%, 23.82 \%$ and $37.40 \%$ at day 1,42 and 84 , respectively (Table 2). PPE-HA-ACRL-2 gels degraded slower and lost $5.42 \%, 8.75 \%$ and $10.94 \%$ of its initial dry weight correspondingly. However, PPE-HA-ACRL-1 gel, with the highest acrylate content, showed only $0.13 \%, 5.45 \%$ and $4.30 \%$ mass loss at the same time points described above (Table 2). It appears that the degradation was dominated by the hydrolysis of the HA side chain in the initial period. This would lead to the diffusion of the PEG-polyacrylate chains out of the network and account for most of the measurable mass loss. After the first 2 weeks, the slower hydrolysis of the PPE-HA-ACRL backbone would come 
into the picture and explain the subsequent slow increase in mass loss. The equilibrated swelling ratio, $q$, can be related to the volumetric swelling ratio by the following equation:

$$
Q=1+\rho_{\text {polymer }}(q-1) \rho_{\text {solvent }},
$$

where $\rho_{\text {polymer }}$ is the density of the dried PPE-HA-ACRL macromer. Since the PEG side chain comprises the main part of the macromer, $\rho_{\text {polymer }}$ can be approximated by the density of PEG $\left(\rho_{\text {PEG }}=1.07 \mathrm{~g} / \mathrm{ml}\right) . \rho_{\text {solvent }}$ is the density of PBS buffer, which is about $1.0 \mathrm{~g} / \mathrm{ml}$. According to the Flory-Rehner equation [31], for hydrogels of high swelling ratios $(Q>10)$, the relationship between $Q$ and the degradation kinetic constant $\left(k^{\prime}\right)$ can be described by the following equation:

$$
Q \sim \mathrm{e}^{3 / 5 k t t} .
$$

So qualitatively, the trend in degradation rate agrees with the change in $q$ (or $Q$ ) as a function of the macromer composition. Detailed study is underway to quantify the relationship among the volumetric swelling ratio $Q$, the degradation kinetic constant $k^{\prime}$ and the average molecular weight between the crosslinks $\left(\rho_{x 1}\right)$.

The cytotoxicity of the PPE-HA-ACRL at different concentrations against GMSC was evaluated by the PreMix WST-1 assay. There was no significant difference in cell response after 1-day culture among different solutions of PPE-HA-ACRL-1, PPE-HA-ACRL-3 and control. The cell viability was calculated by normalizing the absorbance of test samples at 440 $\mathrm{nm}$ to that of the control without any macromer in the medium (Fig. 4). The absorbance of all of culture media with macromer solutions narrowly ranged from 0.7 to 1.2 , which was comparable to the absorbance of culture media $(0.84)$ without any macromer addition.

After encapsulation in the gel and cultured in OM for different periods of time, the GMSC maintained their viability and showed a round morphology (Fig. 5A and B). The cells also formed small clumps in the hydrogels. As shown in the 1- and 3-week samples, the average size of the lacunae increased as degradation of the scaffold proceeded. No mineralization from von Kossa staining was observed for the 1-week samples, but positive staining was evident at week 3 (Fig. 5C and D). Two types of mineralized particles were observed in the samples. The first type appeared to be big dark nodules accumulating around the lacunae, and the second was evident as fine dark particles distributing evenly in the hydrogel scaffold. It has been reported that $\beta$-glycerophosphate can be hydrolyzed in the presence of alkaline phosphatase to give elevated phosphate concentration in the media, which can further lead to abundant hydroxyapatite-like calcium phosphate deposits [32-34]. Since phosphate is one of the degradation products of these hydrogels, it is possible that the phosphate structure of these hydrogels might contribute to a secondary mechanism of mineralization. Work is in progress to elucidate this mechanism by measuring the concentration of phosphate and $\beta$ glycerophosphate as a function of culture time. Hydroxyapatite-like materials have been widely used in bone regeneration studies [20-23]. This study suggests that it would warrant further investigation of the potential of these phosphate- and HA-containing hydrogels in bone tissue engineering applications.

\section{Conclusion}

We have investigated the physical, chemical and biological properties of a biodegradable and photocrosslinked hydrogel built on a polyphosphoester structure. Collectively, the high water content, reasonable mechanical properties, adjustable biodegradation rate and favorable cytocompatibility suggest that these hydrogels might find applications as injectable tissue engineering scaffolds. 


\section{Acknowledgements}

This work is supported by NIH funding (R21EB003203, R21 EB003203) and the Arthritis Foundation Arthritis Investigator Award.

\section{References}

1. Peppas NA, Sahlin JJ. Hydrogels as mucoadhesive and bioadhesive materials: a review. Biomaterials 1996;17:1553-61. [PubMed: 8842358]

2. Lutolf MP, Lauer-Fields JL, Schmoekel HG, Metters AT, Weber FE, Fields GB, Hubbell JA. Synthetic matrix metalloproteinase-sensitive hydrogels for the conduction of tissue regeneration: engineering cell-invasion characteristics. Proc Natl Acad Sci USA 2003;100:5413-8. [PubMed: 12686696]

3. Bryant SJ, Anseth KS. Controlling the spatial distribution of ECM components in degradable PEG hydrogels for tissue engineering cartilage. J Biomed Mater Res A 2003;64:70-9. [PubMed: 12483698]

4. Burdick JA, Mason MN, Hinman AD, Thorne K, Anseth KS. Delivery of osteoinductive growth factors from degradable PEG hydrogels influences osteoblast differentiation and mineralization. J Control Rel 2002;83:53-63.

5. Nakayama Y, Ji-Youn K, Nishi S, Ueno H, Matsuda T. Development of high-performance stent: gelatinous photogel-coated stent that permits drug delivery and gene transfer. J Biomed Mater Res 2001;57:559-66. [PubMed: 11553886]

6. Kaluzynski K, Libiszowski J, Penczek S. Poly(2-hydro-2-oxo-1,3,2-dioxaphosphorinane)— preparation and NMR-spectra. Makromol Chem-Macromol Chem Phys 1977;178:2943-7.

7. Zhao Z, Wang J, Mao HQ, Leong KW. Polyphosphoesters in drug and gene delivery. Adv Drug Deliv Rev 2003;55:483-99. [PubMed: 12706047]

8. Mao, HQ.; Zhao, Z.; Dang, W.; Shipanova-Kadiyala, I.; Leong, KW. Biodegradable poly (phosphoester)s. In: Mathiowitz, E., editor. Encyclopedia of controlled drug delivery. New York: Wiley; 1999. p. 45

9. Xu XY, Yu H, Gao SJ, Mao HQ, Leong KW, Wang S. Polyphosphoester microspheres for sustained release of biologically active nerve growth factor. Biomaterials 2002;23:3765-72. [PubMed: 12109702]

10. Wang J, Zhang PC, Lu HF, Ma N, Wang S, Mao HQ, Leong KW. New polyphosphoramidate with a spermidine side chain as a gene carrier. J Control Release 2002;83:157-68. [PubMed: 12220847]

11. Wang J, Zhang PC, Mao HQ, Leong KW. Enhanced gene expression in mouse muscle by sustained release of plasmid DNA using PPE-EA as a carrier. Gene Ther 2002;9:1254-61. [PubMed: 12215893]

12. Wang J, Mao HQ, Leong KW. A novel biodegradable gene carrier based on polyphosphoester. J Am Chem Soc 2001;123:9480-1. [PubMed: 11562246]

13. Wang S, Wan ACA, Xu XY, Gao SJ, Mao HQ, Leong KW, Yu H. A new nerve guide conduit material composed of a biodegradable poly(phosphoester). Biomaterials 2001;22:1157-69. [PubMed: 11352095]

14. Nguyen KT, West JL. Photopolymerizable hydrogels for tissue engineering applications. Biomaterials 2002;23:4307-14. [PubMed: 12219820]

15. Elisseeff J, Anseth K, Sims D, McIntosh W, Randolph M, Langer R. Transdermal photopolymerization for minimally invasive implantation. Proc Natl Acad Sci USA 1999;96:31047. [PubMed: 10077644]

16. Elisseeff J, McIntosh W, Anseth K, Riley S, Ragan P, Langer R. Photoencapsulation of chondrocytes in poly(ethylene oxide)-based semi-interpenetrating networks. J Biomed Mater Res 2000;51:16471. [PubMed: 10825215]

17. Nuttelman CR, Henry SM, Anseth KS. Synthesis and characterization of photocrosslinkable, degradable poly(vinyl alcohol)-based tissue engineering scaffolds. Biomaterials 2002;23:3617-26. [PubMed: 12109687]

18. Burkoth AK, Anseth KS. A review of photocrosslinked polyanhydrides: in situ forming degradable networks. Biomaterials 2000;21:2395-404. [PubMed: 11055287] 
19. Timmer MD, Shin H, Horch RA, Ambrose CG, Mikos AG. In vitro cytotoxicity of injectable and biodegradable poly(propylene fumarate)-based networks: unreacted macromers, cross-linked networks, and degradation products. Biomacromolecules 2003;4:1026-33. [PubMed: 12857088]

20. Barralet JE, Grover L, Gaunt T, Wright AJ, Gibson IR. Preparation of macroporous calcium phosphate cement tissue engineering scaffold. Biomaterials 2002;23:3063-72. [PubMed: 12102177]

21. Xu HHK, Quinn JB, Takagi S, Chow LC. Synergistic reinforcement of in situ hardening calcium phosphate composite scaffold for bone tissue engineering. Biomaterials 2004;25:1029-37. [PubMed: 14615168]

22. Phan PV, Grzanna M, Chu J, Polotsky A, El-Ghannam A, Van Heerden D, Hungerford DS, Frondoza CG. The effect of silica-containing calcium-phosphate particles on human osteoblasts in vitro. J Biomed Mater Res A 2003;67A:1001-8. [PubMed: 14613250]

23. Kai T, Shao-Qing G, Geng-Ting D. In vivo evaluation of bone marrow stromal-derived osteoblastsporous calcium phosphate ceramic composites as bone graft substitute for lumbar intervertebral spinal fusion. Spine 2003;28:1653-8. [PubMed: 12897487]

24. Bryant SJ, Nuttelman CR, Anseth KS. Cytocompatibility of UV and visible light photoinitiating systems on cultured NIH/3T3 fibroblasts in vitro. J Biomater Sci Polym Ed 2000;11:439-57. [PubMed: 10896041]

25. Li Q, Williams CG, Sun DDN, Wang J, Leong K, Elisseeff JH. Photocrosslinkable polysaccharides based on chondroitin sulfate. J Biomed Mater Res A 2004;68A:28-33. [PubMed: 14661246]

26. Wang DA, Williams CG, Li QA, Sharma B, Elisseeff JH. Synthesis and characterization of a novel degradable phosphate-containing hydrogel. Biomaterials 2003;24:3969-80. [PubMed: 12834592]

27. Zhu WB, Iatridis JC, Hlibczuk V, Ratcliffe A, Mow VC. Determination of collagen-proteoglycan interactions in vitro. J Biomech 1996;29:773-83. [PubMed: 9147974]

28. Peter SJ, Liang CR, Kim DJ, Widmer MS, Mikos AG. Osteoblastic phenotype of rat marrow stromal cells cultured in the presence of dexamethasone, beta-glycerolphosphate, and l-ascorbic acid. J Cell Biochem 1998;71:55-62. [PubMed: 9736454]

29. Pittenger MF, Mackay AM, Beck SC, Jaiswal RK, Douglas R, Mosca JD, Moorman MA, Simonetti DW, Craig S, Marshak DR. Multilineage potential of adult human mesenchymal stem cells. Science 1999;284:143-7. [PubMed: 10102814]

30. Iatridis JC, Weidenbaum M, Setton LA, Mow VC. Is the nucleus pulposus a solid or a fluid? Mechanical behaviors of the nucleus pulposus of the human intervertebral disc. Spine 1996;21:117484. [PubMed: 8727192]

31. Flory, PJ. Principles of polymer chemistry. Ithaca: Cornell University Press; 1953. p. 672

32. Halvorsen YDC, Franklin D, Bond AL, Hitt DC, Auchter C, Boskey AL, Paschalis EP, Wilkison WO, Gimble JM. Extra-cellular matrix mineralization and osteoblast gene expression by human adipose tissue-derived stromal cells. Tissue Eng 2001;7:729-41. [PubMed: 11749730]

33. Khouja HI, Bevington A, Kemp GJ, Russell RG. Calcium and orthophosphate deposits in vitro do not imply osteoblast-mediated mineralization: mineralization by betaglycerophosphate in the absence of osteoblasts. Bone 1990;11:385-91. [PubMed: 2078432]

34. Boskey AL, Guidon P, Doty SB, Stiner D, Leboy P, Binderman I. The mechanism of betaglycerophosphate action in mineralizing chick limb-bud mesenchymal cell cultures. J Bone Miner Res 1996;11:1694-702. [PubMed: 8915777] 


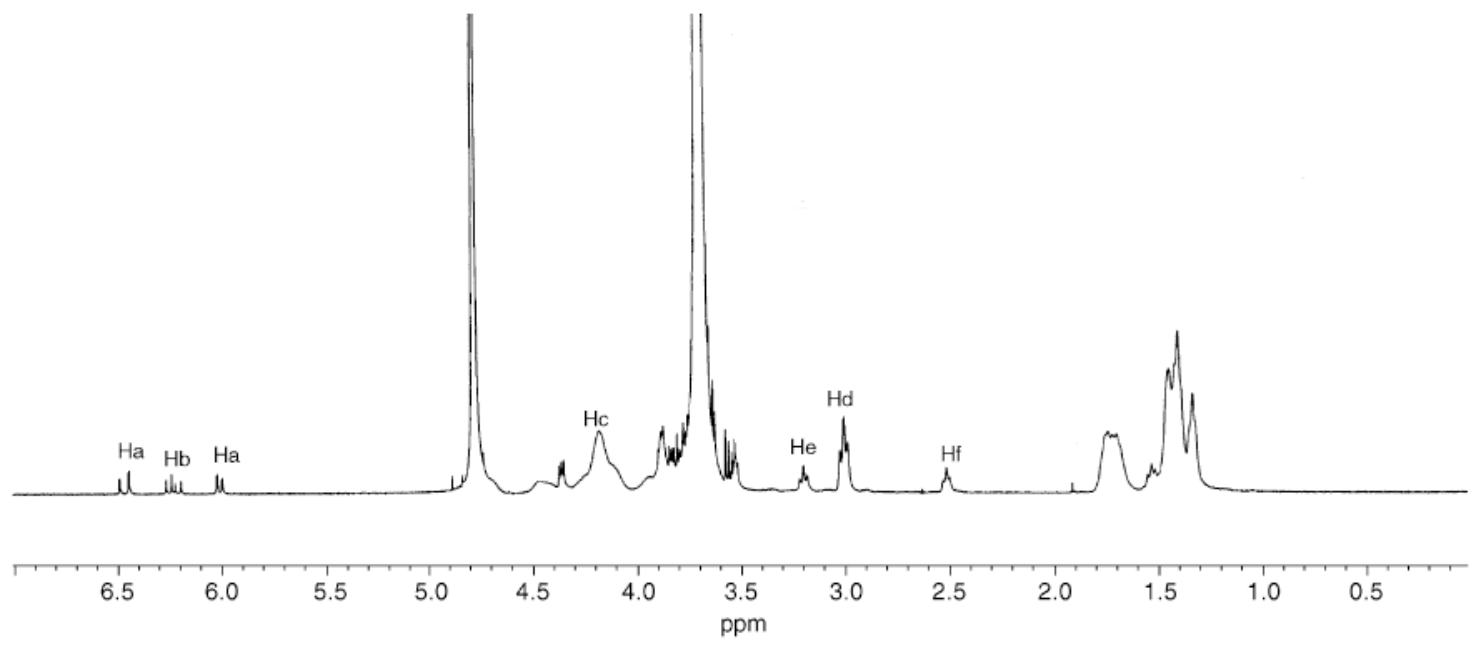

Fig. 1.

${ }^{1} \mathrm{H}$ NMR spectrum of PPE-HA-ACRL in $\mathrm{D}_{2} \mathrm{O}$. 


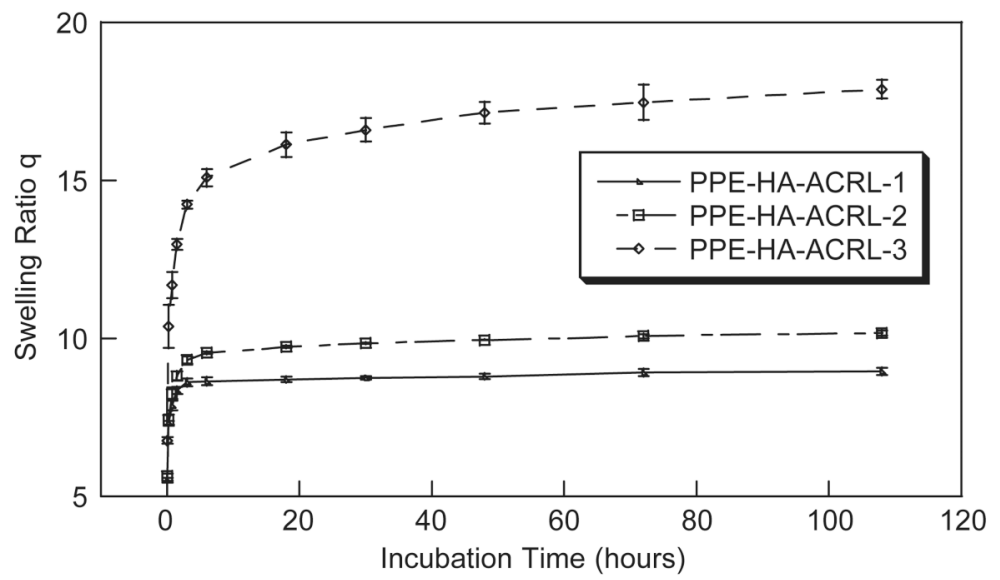

Fig. 2.

Swelling behavior of PPE-HA-ACRL hydrogels. 


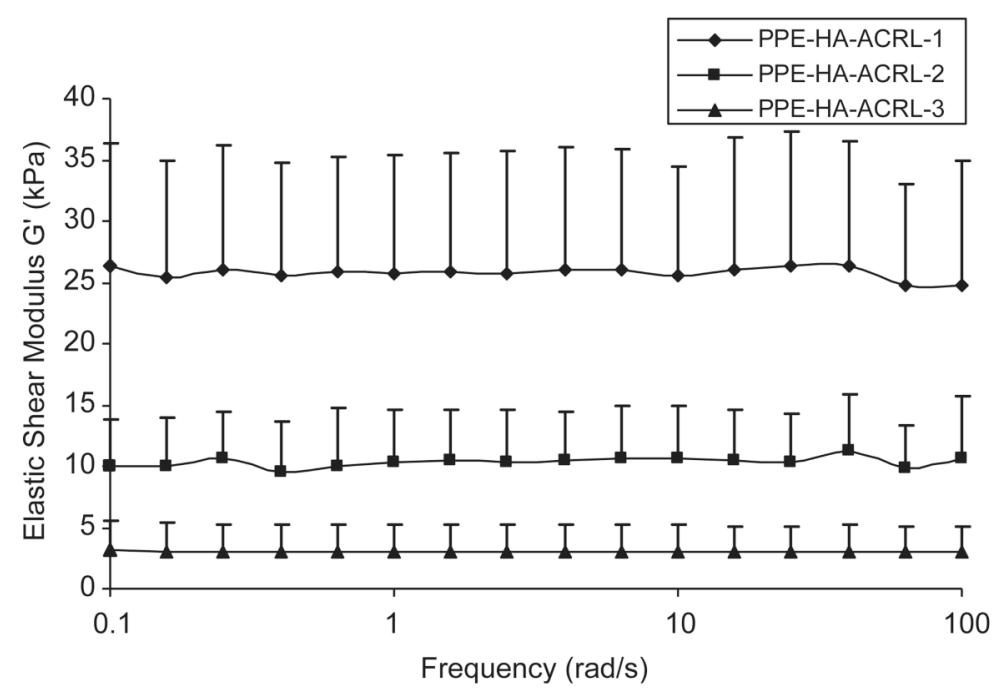

Fig. 3.

Rheological characterization of PPE-HA-ACRL hydrogels. 


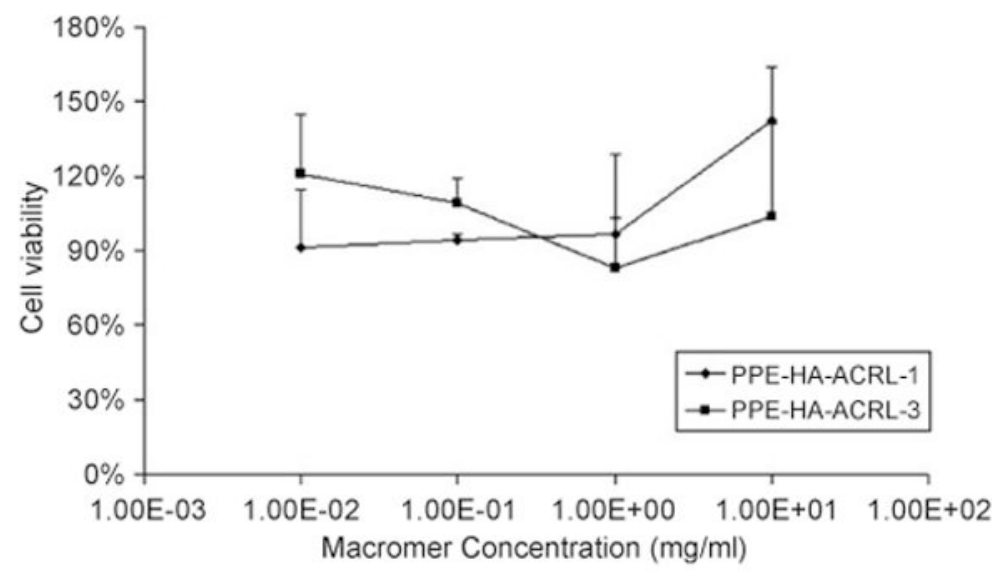

Fig. 4.

Cytotoxicity test of PPE-HA-ACRL macromer. PreMix WST-1 assay was performed to check the cytotoxicity of unreacted PPE-HA-ACRL macromer in the medium. 

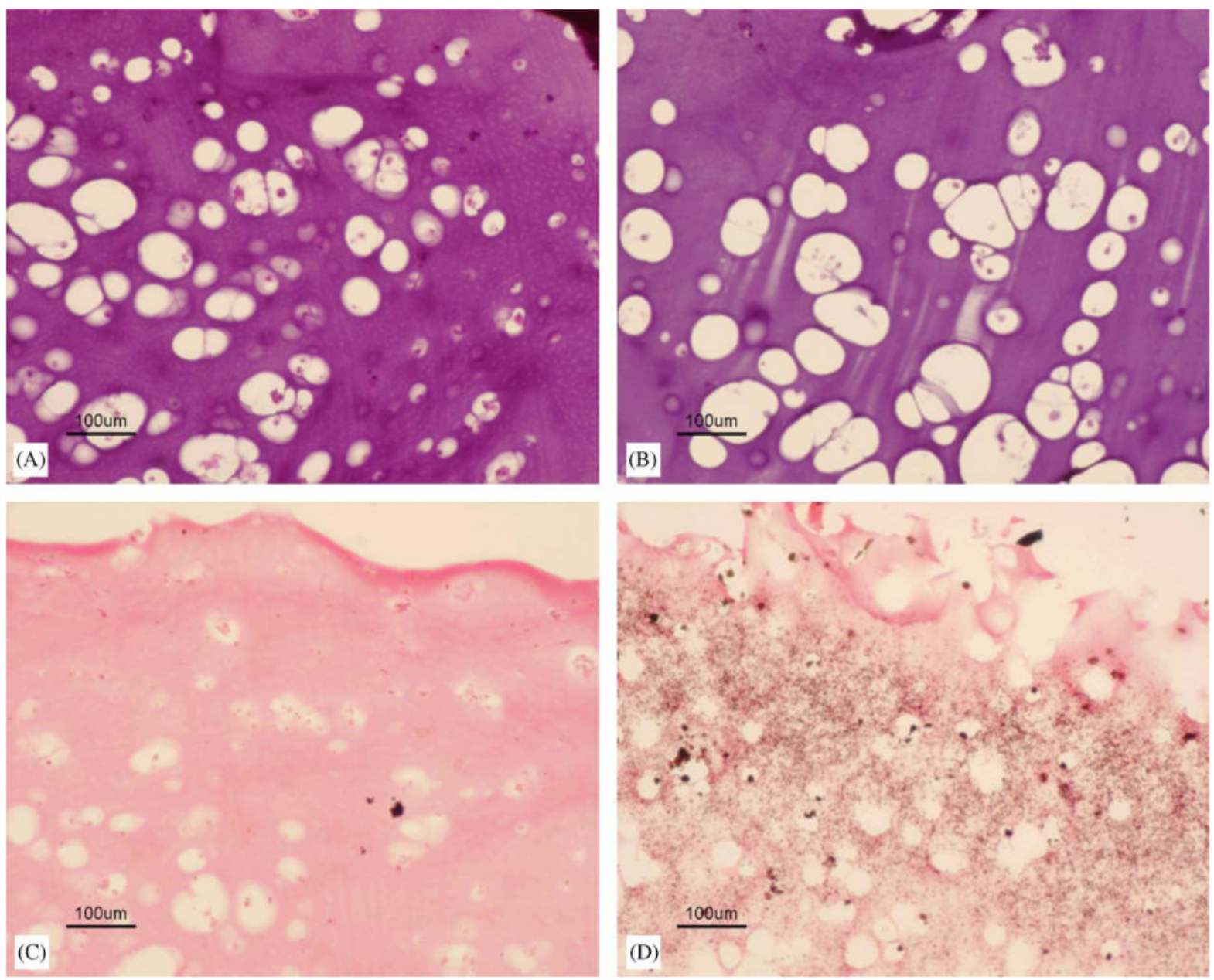

Fig. 5.

Histology staining. (A) H\&E staining for 1-week samples encapsulated with GMSCs $(10 \times)$, bar $=100 \mu \mathrm{m}$; (B) H\&E staining for 3-week samples encapsulated with GMSCs $(10 \times)$, bar = $100 \mu \mathrm{m}$; (C) Von Kossa staining for 1-week samples encapsulated with GMSCs $(10 \times)$, bar = $100 \mu \mathrm{m}$; and (D) Von Kossa staining for 3-week samples encapsulated with GMSCs $(10 \times)$, bar $=100 \mu \mathrm{m}$. 

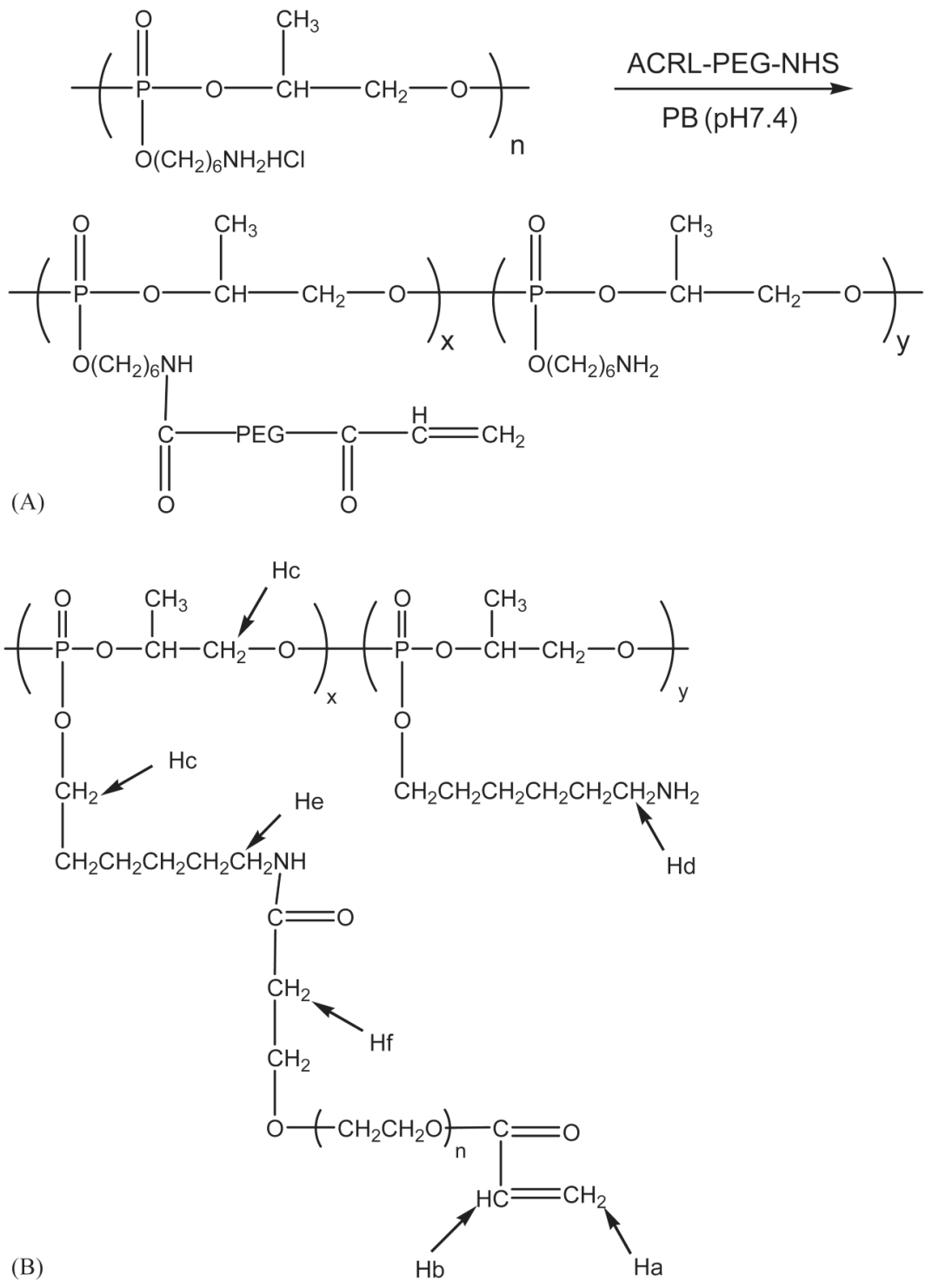

\section{Scheme 1.}

(A) Synthesis of PPE-HA-ACRL. The PPE-HA was modified with acrylate groups through the reaction between the amine in PPE-HA side chains and ACRL-PEG-NHS and (B) the protons on PPE-HA-ACRL are labeled to correspond to their peaks in the ${ }^{1} \mathrm{H}$ NMR spectra. 
Table 1

Effect of the molar ratio of reaction reagents on the composition of the PPE-HA-ACRL macromer

\begin{tabular}{lllll}
\hline Code & $\begin{array}{l}\text { Molar ratio of ACRL- } \\
\text { PEG-NHS to PPE-HA } \\
\text { units }\end{array}$ & $\begin{array}{l}\text { PEG chains per 100 } \\
\text { units }\end{array}$ & $\begin{array}{l}\text { Free amino groups } \\
\text { per 100 units }\end{array}$ & $\begin{array}{l}\text { Double bond per 100 } \\
\text { units }\end{array}$ \\
\hline PPE-HA-ACRL-1 & $4: 10$ & 37.9 & 50.1 & 26.4 \\
PPE-HA-ACRL-2 & $2: 10$ & 22.6 & 69.8 & 15.5 \\
PPE-HA-ACRL-3 & $1: 10$ & 13.6 & 83.4 & 8.3 \\
\hline
\end{tabular}


Table 2

Degradation profiles of PPE-HA-ACRL hydrogels in PBS

\begin{tabular}{llll}
\hline Degradation time & \multicolumn{1}{l}{ Mass Loss (\%) } & \\
\cline { 2 - 4 } & Day 1 & Day 42 & Day 84 \\
\hline PPE-HA-ACRL-1 & $0.13 \pm 12.22$ & $5.45 \pm 1.56$ & $4.30 \pm 1.56$ \\
PPE-HA-ACRL-2 & $5.42 \pm 4.12$ & $8.75 \pm 0.25$ & $10.94 \pm 8.92$ \\
PPE-HA-ACRL-3 & $13.43 \pm 5.39$ & $23.82 \pm 1.67$ & $37.40 \pm 3.14$ \\
\hline
\end{tabular}

